\title{
KARST HYDROLOGY IN ANCIENT MYTHS FROM ARCADIA AND ARGOLIS, GREECE
}

\author{
O KRAŠKI HIDROLOGIJI V STARIH MITIH GRŠKIH POKRAJIN \\ ARKADIJE IN ARGOLIDE
}

\author{
Cindy CLENDENON ${ }^{1}$
}

\begin{abstract}
UDC 556.3:398.22(495.21)

Cindy Clendenon: Karst Hydrology in Ancient Myths from Arcadia and Argolis, Greece

The history of karst science includes ancient Greek literary narratives that describe the behavior of karstic waters, yet remain largely unrecognized for their hydrogeological relevance. This paper integrates karst hydrology with ancient myths and travelogues describing natural features in Arcadia and Argolis of the Greek Peloponnese. The karstic landscapes of these two regions were figuratively represented in the interrelated myths of the Danaids, Poseidon, and Amymone. In a nonmythical report of a historical occurrence, a deer hunter chased a deer into the temporarily flooded polje of ancient Stymphalus, but a sudden dislodging of the sinkhole debris plug caused the lake to drain so rapidly that the hunter and his prey were suctioned helplessly down into the whirlpool. Other ancient narratives described the subterranean connection of the Stymphalian polje and the Argolic springs of Erasinus. Some accounts stemmed from an ancient religious practice of throwing items into waters to propitiate the water gods: In one case, the watery disposition of propitiatory wreaths was determined by interweavings of the surface and subsurface components of the two karstic rivers named Alpheus and Eurotas. In other ancient accounts, certain rivers were said to sink underground at the coastline, travel through the bed of a bay or sea, and resurge as subaerial freshwater springs on the opposite shore of the saline waterbody.

Keywords: hydromythology, geomythology, history of karstology, ancient water tracing, Greece.
\end{abstract}

\author{
Izvleček \\ UDK 556.3:398.22(495.21) \\ Cindy Clendenon: $O$ kraški hidrologiji $v$ starih mitih grških \\ pokrajin Arkadije in Argolide
}

Zgodovina krasoslovja vključuje tudi grške antične opise kraških voda, ki pa so redkokdaj upoštevani kot pomembni za hidrogeologijo. Ta članek združuje kraško hidrologijo $\mathrm{z}$ antičnimi miti in potopisi, ki govore o naravnih pojavih Arkadije in Argolide na polotoku Peloponezu. Ti dve kraški pokrajini sta poosebljeni v prepletajočih se mitih o Danaidah, Pozejdonu in Amimoni. Zgodovinsko poročilo govori o dogodku, ki se je pripetil na občasno poplavljenem Stimfalskem polju: lovec je zasledoval jelena, ko se je nenadoma vdrl s plavjem zamašen ponor in je voda pričela tako hitro odtekati, da je vrtinec posrkal v podzemlje brezmočnega lovca in njegov plen. Drug stari opis govori o podzemeljski zvezi Stimfalskega polja in izvira Erazin v Argolidi. Nekatere pripovedi izvirajo iz stare verske navade metanja darov v vodo, da bi pomirili vodne bogove: $\mathrm{z}$ metanjem darilnih vencev so ugotovili prepletanje dveh kraških rek, Alfeja in Evrota. Druga stara poročila govore o nekaterih rekah, ki na obali ponikajo, tečejo pod dnom zaliva ali morja in se ponovno pojavijo kot sladkovodni izviri na drugi strani telesa slane vode.

Ključne besede: idromitologija, geomitologija, zgodovina krasoslovja, antično sledenje voda, Grčija.

\footnotetext{
${ }^{1}$ Michigan Dept. of Environmental Quality, c/o Fineline Science Press, P.O. Box 10014, Lansing, Michigan 48901 USA, e-mail: c2editor@bloombb.com
}

Received/Prejeto: 14.07 .2008 


\section{INTRODUCTION}

Two-thirds of modern Greece is dominated by limestones, many of which are karstified. In the centuries preceding and following Homer (c. $800 \mathrm{BC}$ ), the ancient Greeks amassed stories involving karst landscapes on the Greek mainland and throughout the Mediterranean and West Asia. Karstlands provided the environmental settings for an array of Greek myths, religious practices, and travelogues. The stories that ultimately were recorded by Greek mythographers and that survive today can provide insight into the hydrogeology of the ancient Greek world.

The study of karst structures as depicted in myth falls under the umbrella of geomythology, which is described below. But the study of karst waters and myth is better identified as hydromythology, which fundamentally means myths about water, and whose definition is not to be confused with the term's alternate usage to indicate misconceptions or disinformation about water resources.

Thirty years ago William Back of the U.S. Geological Survey posited an anthropologically oriented definition of hydromythology (Back 1978, 1981). This paper redefines hydromythology to mean the study of myths, legends, and folklore inspired by the natural occurrence of water in the ecological environment, and the objective assessment of these nonscientific accounts from the perspective of hydrologic plausibility, including karst hydrology (Clendenon 2009a). In other words, hydromythology is the study of the hydrologic origins of tales that historically explained natural water features in nonscientific terms.

\section{GEOMYTHOLOGY}

In May 1967 the late Dorothy B. Vitaliano (1916-2008), a volcanologist and technical translator for the U.S. Geological Survey, gave a geology lecture wherein she publicly presented her newly coined term, "geomythology." Six months later, a slightly revised text of her lecture was published (Vitaliano 1968). Five years later, Vitaliano's book examined the possible geologic fundaments of selected global myths and traditions, particularly stories of natural catastrophe (Vitaliano 1973).

For more than three decades, Vitaliano was among a minority of traditionally trained scientists who suggested connections between physical evidence and ancient stories, including Plato's tale of Lost Atlantis (Vitaliano 1971). The "new science" aspect of geomythology also attracted pseudoscientists, geomancers, and others outside of mainstream science. Perhaps because it straddled the line between science and nonscience, geomythology remained a fledgling field of inquiry.

Recently geomythology began to emerge from the shadows when major geological organizations started taking an interest. In this decade an increasing number of scientists are mining mythological storylines to glean information about the history of geohazards such as volcanoes, earthquakes, and tsunamis. Certain universities have added seminars and courses on myth and geology. Today geomythology encompasses geotourism as well as scientific topics as diverse as cosmogony, geocatastrophism, volcanism, sea change, sedimentology, surficial geology, fossils, and cultural and spiritual beliefs involving geologic features.

\section{KARST, THE GEOMYTHOLOGICAL WALLFLOWER}

Despite geomythology's inclusivity as a field of inquiry, English-language books and journal articles about geomythology rarely address hydrology unless it involves either a human crisis or a natural disaster. Publications which substantively examine karst hydrology and Greek mythology are practically nonexistent.

Recent publications recognize certain Greek geomyths, but in a highly selective manner (Hale et al. 2003; Broad 2006; Piccardi \& Masse 2007). A book about Aegean geology rarely mentions karst or Greek myth (Higgins \& Higgins 1996). A book about Greek river gods is little more than a popular travelogue (Brewster 1997). Four publications recognize the critical role of karst in ancient Greek settlement, but do not mention myths (Crouch 1990, 1993, 1996, 2003). Paleogeomorphological studies involving ancient Greek landscapes have considered information from ancient literary sources, but give little or no attention to ancient texts involving karst (Zangger 1991; Kraft et al. 2003, 2005). Historical overviews of karstology credit a few ancient Greek and Latin philosophers and writers with observing hydrogeological phenomena, but the overviews provide no specific information about the karstic waters of Greece in relation to myths (LaMoreaux 1991; Kranjc 2000; Fetter 2004; LaMoreaux \& LaMoreaux 2007; White 2007).

Starting with the ancient scholiasts, commentators have repeatedly interpreted certain mythological labors of Heracles (Hercules) as idealized representations of pre-classical Greek drainage and water-control activities in selected river valleys, floodprone poljes, and pestilential marshes, including the Peloponnesian regions of Copais, Feneos, Stymphalus, and Lerna. But in terms of natural karst hydrology unaffected by human modifica- 


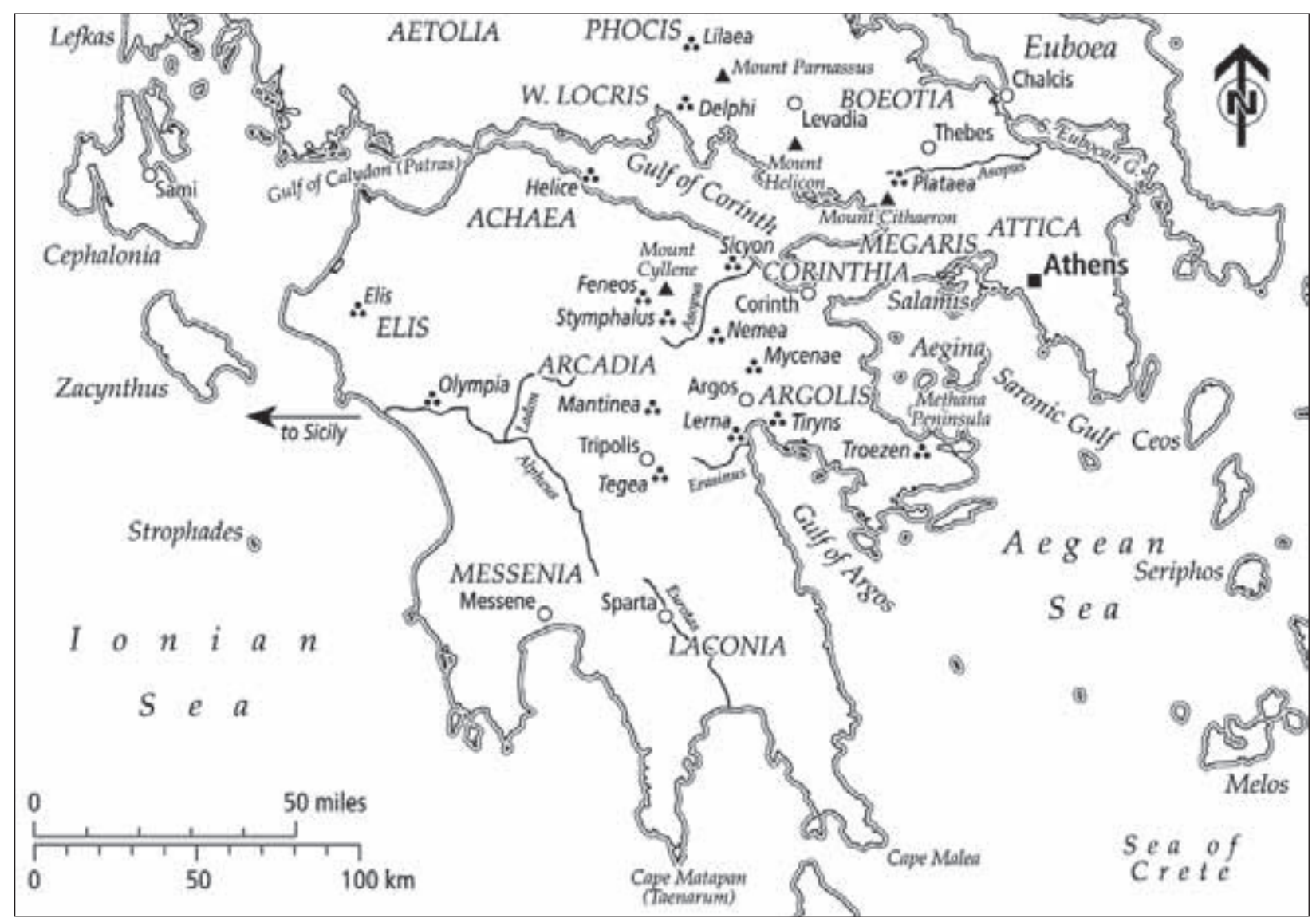

Fig. 1: The Greek Peloponnese and vicinity, showing ancient and modern features. Modified after Clendenon (2009a).

tion, only the article by Mariolakos \& Mariolakos (2004) substantively discusses Greek karst terranes related to Greek mythology. They speculated that the ancient Greeks may have envisioned the Olympian god Poseidon as traveling underground through karstic conduits of Arcadia and Argolis. The paper was followed in 2005 by Ilias D. Mariolakos's leadership of a two-day tour of selected sites in Greece where karstic structures may have been associated with the mythological actions of Poseidon and Heracles (Mariolakos 2005).

To address the paucity of references to karst and mythology of the ancient Greek world, this author conducted a wide-ranging survey of Greek myths and trav- elogues, revealing that most of the hydrogeological systems depicted in Greek myth were at least partly karstic (Clendenon 2009a). The book presents the first integration of karstology and hydrology with Greek and Latin narratives spanning the centuries from the poet Homer to the geographer Pausanias, or roughly from $800 \mathrm{BC}$ to $200 \mathrm{AD}$. The following discussion distills portions of the book specific to ancient Arcadia and Argolis. A related paper (Clendenon, in prep.) provides additional information about the anciently alleged submarine extensions of the karstic Arcadian River Alpheus and the karstic Turkish River Meander.

\section{KARSTIC CONNECTIONS BETWEEN ARCADIA AND ARGOLIS}

Ancient Arcadia and Argolis were two adjoining districts in the large peninsula of southern Greece known as the Peloponnese. The combined land area of these ancient regions extended from near the Ionian Sea in the west to the Gulf of Argos in the east (Fig. 1). The Gulf of Argos is an arm of the Aegean Sea. The ancient boundaries of Arcadia and Argolis were different than today's prefectures of the same names.

As early as the fourth century BC, the Greek philosopher Aristotle wrote about the karstic peculiarities 
of Arcadia's streams. In his treatise entitled Meteorology (c. $350 \mathrm{BC}$ ), Aristotle correctly deduced that because Arcadia is ringed by mountains, its waters can reach the sea only through subterranean channels which today are known to be karstic. More than two millennia later, Leake (1830) began to draw modern attention to the land-locked nature of Arcadia's poljes.

Water tracing studies summarized by Higgins \& Higgins (1996) demonstrated that most surface waters of Arcadia are diverted underground through waterswallowing sinkholes (ponors) and then move eastward and southeastward to reappear as terrestrial springs and submarine springs (vruljas) along the west coast and western seabed of the Gulf of Argos. Only the subterranean waters in Arcadia's Feneos polje and the Orchomenos polje immediately to its south flow westward to ultimately enter the Ionian Sea. These poljes are linked by sinkholes and underground passages to headwater springs of the River Ladon, a tributary of the River Alpheus (Fig. 1).

The following sections describe ancient accounts of Arcadian waters that traveled eastward to Argolis. The Feneos polje and its westward karstic connection to springs of the River Ladon are not discussed because this region has been well documented by the ancient geographers Eratosthenes (as quoted by Strabo), Strabo (c. 15 $\mathrm{AD}$ ), and Pausanias (c. $175 \mathrm{AD}$ ), and by modern travelers (Leake 1830; Baird 1856; Frazer 1898; Baker-Penoyre 1902).

\section{THE UNTILLED PLAIN}

Pausanias was a Romanized Greek traveler and geographer who lived in the second century. In his treatise on Arcadia, Pausanias wrote about the Untilled Plain, which today is described as a small, floodprone polje among a series of poljes in the greater plateau region of Arcadia (Mariolakos \& Mariolakos 2004; Milanovic 2004). Rainwater coming down into the plain from the surrounding mountains prevented ancient Greeks from tilling the land. Pausanias stated that if it were not for drainage afforded by a sinkhole, the Untilled Plain would have formed a semi-permanent to permanent lake.

According to Pausanias, surface water that disappeared through a sinkhole in the Arcadian Untilled Plain reappeared in a submarine spring offshore of Dine (Dini), slightly south of Lerna (Fig. 1). Leake (1830) equated Pausanias's submarine spring of Dine with the modern submarine spring of Anavalos, one of a group of fresh-water springs in the nearshore seabed. The fresh water rose from the seabed with such force that it roiled the sea surface and created far-reaching ripples. Leake estimated the submarine issuance to be at least $15 \mathrm{~m}$ in diameter. Boblaye (1835) witnessed a large amount of sand roiling up from the seabed.

Today the submarine springs are known as the Anavalos, Anavalos-Kiveri, and Saint George springs. The Kiveri spring group rises 15-50 m offshore, and a large spring to the south occurs about $300 \mathrm{~m}$ offshore (Morfis \& Zojer 1986, as reported by Higgins \& Higgins 1996). The discharge system comprised of four main coastal and submarine springs has an average total discharge rate exceeding $10 \mathrm{~m}^{3} / \mathrm{s}$ (Fleury et al. 2007). In the 1960s a semi-circular concrete gravity dam was constructed on the seabed to capture some of the slightly saline springwaters for the purpose of irrigation (Lemon 1999; Milanovic 2004).

The spring of Anavalos farthest offshore is fed uniquely from the sinkhole in the former Lake Taka, south of Tripolis and west of Tegea (Morfis \& Zojer 1986, as reported by Higgins \& Higgins 1996). Mariolakos \& Mariolakos (2004) identified the source of the Dine spring as the present-day Nestani sinkhole northeast of Tripolis. They suggested that the Nestani is one of the Mantinean sinkholes of ancient fame. The Mantinean polje and sinkholes are known for their roles in ancient military strategies during the First Battle of Mantinea (418 BC) and subsequent battles, which Loring (1895) and Leake (1830) describe.

\section{THE CONNECTED WATERS OF STYMPHALUS AND ERASINUS}

The Stymphalian polje occupied a spring-fed plain about $25 \mathrm{~km}$ south of the Gulf of Corinth (Fig. 1). Pausanias indicated that in winter, the polje filled with springwater, rainwater, and runoff from the bordering mountains, thereby creating a temporary lake named Stymphalus; but in summer, the pooled waters started disappearing, yielding a dry lakebed by summer. Pausanias noted that in wet weather, the River Stymphalus issued from Lake Stymphalus; but in dry weather, the river came directly from the springs. Pausanias observed that the river water descended into a large sinkhole. Frazer (1898) generally confirmed Pausanias's descriptions.

The ancient Greeks and Romans accurately identified the subterranean connection between the polje of Stymphalus and the subaerial springs that form the River Erasinus in coastal Argolis (Fig. 1). In the fifth century BC, Greek historian Herodotus wrote in Histories that the water of Lake Stymphalus disappears through a dark chasm, then resurfaces in Argos where it becomes the River Erasinus. Greek mathematical geographer Eratosthenes of Cyrene, who lived in the third century BC, similarly reported that the River Erasinus 
flows from near Stymphalus, passes under a mountain, and resurfaces in Argos. In Metamorphoses (c. 10 AD), Roman poet Ovid wrote that the engulfed stream of Stymphalus "glides in secret eddies underground" and then returns to the surface as "a lordly river" (Erasinus) in the Argive fields.

In his treatise Geography (c. $15 \mathrm{AD}$ ), Romanized Greek geographer Strabo stated that the Stymphalian water travels underground for 200 stadia before resurfacing as springs of the River Erasinus. Although there is no universally accepted conversion factor for an ancient stade, a conservative estimate yields $38 \mathrm{~km}$.

The ancient accounts were correct in linking the Arcadian Lake Stymphalus with the Argive River Erasinus. Gell (1823) reported a modern claim by local inhabitants that if a large number of cones from fir-trees are thrown into the Stymphalian sinkhole, they will resurge at the Erasinus spring. Perhaps the ancient Greeks used a similar method of water tracing using physical objects.

Modern water tracing experiments have shown that water draining through sinkholes in the Stymphalian polje and the south-adjoining poljes of Alea and Scotini ultimately discharges from springs along the northwest Gulf of Argos (Morfis \& Zojer 1986, as summarized by Higgins \& Higgins 1996). Springs that feed the River Erasinus issue at Kephalari, a village situated about 3 $\mathrm{km}$ southwest of Argos. Here the subterranean water is forced to the surface along a fault. The River Erasinus flows overland $6 \mathrm{~km}$ to the Gulf of Argos.

Long before modern tracing methods confirmed the flow paths, Leake (1830) concurred with ancient conclusions that the River Erasinus is the same watercourse as the River Stymphalus. Baird (1856) estimated that the distance between the place of the river's sinking at Lake Stymphalus and the place of its resurgence as the Erasinus spring is $40 \mathrm{~km}$, which reasonably matches Strabo's ancient account.

Travelers such as Gell (1810), Dodwell (1819), and Leake (1830) ascertained Pausanias's ancient account by observing several large springs issuing from the foot of cavernous Mt Chaon, a mountain located on the southwest edge of the plain of Argos near the Gulf of Argos. Baird (1856) stated that the subterranean resurgence of the River Erasinus "bursts out from the rock with great violence," thus indicating the potential for occasionally powerful discharges. Boblaye (1835) noticed the abundant bubbles emerging from the spring, presumably from carbon dioxide degassing.

\section{THE STYMPHALIAN SINKHOLE}

Regarding the sinkhole of Stymphalus, Gell (1823) said that it appeared to be of great depth. But its orifice, espe- cially during the water-sparse summer, was susceptible to plugging, whether by natural processes or by the deliberate placement of objects such as stones or hay. Gell's comment about deliberate sinkhole plugging recalls Strabo's ancient report that Iphicrates, an Athenian general who lived in the fourth century BC, was besieging the city of Stymphalus and tried to flood the plain by blocking the sinkhole throat with a large quantity of sponges, but desisted when Zeus sent an omen from the sky.

The Stymphalian sinkhole was the site of a dramatic natural event that allegedly happened in the second century during Pausanias's lifetime. One day, during the religious festival of Stymphalian Artemis, a log fell into the mouth of the sinkhole into which the River Stymphalus normally descended. According to Pausanias, this blockage caused the riverine plain to flood for a distance of $75 \mathrm{~km}$ upstream of the plugged hole.

Meanwhile, a hunter chased a deer that fled into the high waters of the Stymphalian lake. In his excitement, the hunter swam after the deer. By this time, the sinkhole had unplugged, enabling the lake to drain rapidly. The power of the whirlpool swallowed the swimming deer and her pursuer. The sinkhole then gulped the water of the River Stymphalus, so that by the next day, the formerly flooded Stymphalian plain was nearly dry.

In this author's interpretive speculation, the logplugged sinkhole was the same one that swallowed the deer hunter. The log obstruction must have become buoyant and either floated out or was otherwise jostled away from the sinkhole throat after the hole became fully submerged. Once the stymied drainage suddenly accelerated, the water pouring down the submerged hole (ponor) must have created a whirlpool effect, overpowering the deer and the hunter when they swam across the zone of suction.

The drowning of a deer and a human in a sinkhole/ ponor is an unfortunate but unexceptional natural occurrence. Downward flows through ponors can range from a trickle to a huge flush. For example, in the Dinaric karst region of the eastern Adriatic, the swallowing capacity of some major ponors ranges from $20 \mathrm{~m}^{3} / \mathrm{s}$ to $120 \mathrm{~m}^{3} / \mathrm{s}$ (Milanovic 2004). It is conceivable that, on at least one occasion, the ancient sinkhole of Stymphalus drained with enough suction to pull down a human swimmer, just as Pausanias reported.

\section{THE SPRINGS OF LERNA}

In antiquity, springs at and near the resurgence which formed the River Erasinus contributed to Lake Lerna, a large fresh-water lagoon separated from the Gulf of Argos by a beach barrier (Zangger 1991). In the early 
Bronze Age, the maximum size of Lake Lerna was about 2 by $5 \mathrm{~km}$ (Higgins \& Higgins 1996). The lake was permanently drained in the modern nineteenth century.

The ancient springs of Lerna were famous for their high quality. According to Pausanias, Lerna's springs continued to flow in summer, even though other seasonal surface waters dried up. These claims are consistent with the known capability of large karstic springs to flow perennially, and with the tendency for the modern-day karstic River Panitsa (the ancient Inachus) near Argos to cease flowing in summer (Higgins \& Higgins 1996). According to reports of travelers, the springs of Lerna remained productive at the times of their visits (Gell 1810; Dodwell 1819; Leake 1830).

Strabo observed that Argos lay in a district devoid of surface water, yet it had an abundance of wells. This statement is consistent with the modern understanding that karst landscapes often experience drought at the surface when there is abundant water underground (Williams 2008).

In mythological terms, the ancient Greeks attributed the loss of surface flow in Argos's karstic rivers to a vengeful act by the god Poseidon, who was ordered by a tribunal of Argolic river gods to cede his patronage of Argos to the goddess Hera. Enfuriated over the loss of his entitlement, Poseidon caused a tsunami in the Gulf of Argos and also made the surface waters of Argos's rivers sink underground. From that moment, the river channels contained water only after a rain. Poseidon even dried up the springs of Argos.

According to this mythological history, the land surface of ancient Argolis remained largely waterless until Poseidon fell in love with Amymone, the blameless Danaid. The backstory involves Danaus and his twin brother Aegyptus, who were grandsons of the River Nile. Danaus ruled the territory of Libya, whereas Aegyptus ruled Egypt and Arabia.

Danaus and his wife had fifty daughters collectively called the Danaids. Danaus and his daughters emigrated from Egypt to ancient Argolis, sailing to the Peloponnese and disembarking on the Gulf of Argos coast just south of Lerna near the modern village of Kiveri, which was mentioned previously as the site of submarine springs.

The fifty sons of Aegyptus followed Danaus to Argolis and demanded to be wed to the Danaids. Under threat, Danaus consented to the marriages. But he gave the girls daggers and instructed them to kill their bridegrooms on their wedding night. All the Danaids except one killed their bridegrooms.

In some accounts, the goddess Athena and the god Hermes, under orders from Zeus, purified the Danaids of their crimes. But in other accounts, the Danaids are forever punished in Tartarus, the deepest part of the Underworld, by fruitlessly drawing water in pitchers with open bases. In some translations, the Danaids carry water to fill a leaky storage container.

The one Danaid who did not kill her husband was Hypermnestra, who in Hellenistic times was identified with Amymone. Poseidon saved Amymone from an amorous satyr by hurling his trident at the satyr and scaring him away. Although Poseidon's trident missed the satyr, it lodged firmly in a rock. When Amymone told her rescuer that she had been seeking water, the lovestruck god directed her to draw the trident from the rock. As she did, three streams of water flowed from the Earth, one for each of the trident's prongs. In this way, Poseidon revealed to Amymone the springs of Lerna.

\section{ENCRYPTED KARSTOLOGY}

Some commentators interpret the story of the Danaids in the context of Orphic mysteries, whereas others think it represents a transition from matriarchy to patriarchy, or a refusal of women to accept the rite of marriage, or various other sociopolitical statements. Other commentators see a story of ancient water-control engineering. Although some of these interpretations may be correct, this author proposes that certain aspects of the stories of the Danaids, Poseidon, and Amymone are figurative descriptions of the natural behavior of water in the karst terranes of Argolis.

The richness of the ancient story stems from its apt representations of karstic landscapes. The leaky water-jars of the Danaids are a fitting analogy of how karstic waterbodies lose their surface-water component through pits and ponors. The breaks in the jars probably represented these karstic openings through which surface waters sank. The punctures in the rockface created by Poseidon's trident probably represented the orifices through which groundwater emerged as karst springs. The earthquake associated with Poseidon's punitive tsunami probably caused certain springs in Argolis to cease flowing (e.g., the springs of Argos), and other springs to start flowing (e.g., the springs of Lerna). These interpretations align with suggestions of Mariolakos \& Mariolakos (2004) that certain myths of Poseidon set in Arcadia and Argolis were encrypted accounts of the physical and geological evolution of the area east of Tripolis (Fig. 1). 


\section{ANCIENT INCIDENTAL WATER TRACES}

Leake (1830) was impressed that the ancient Greeks understood the route of the subterranean Stymphalus-Erasinus river, even though it passed under several mountains and intervening ridges. Leake surmised that the ancient Greeks could have ascertained the subterranean route by tossing lightweight substances into the Stymphalian sinkhole and then watching for their reappearance in springs near Argos. Although Leake did not give the ancient evidence leading to this supposition, it would seem that he was familiar with the Greeks' happenstance methods of tracing subterranean water paths: namely, by recognizing small physical objects that were carried by water currents from sinkhole inlets to spring outlets.

The ancient Greeks commonly threw sweetcakes, wreaths, human hair, animals, and various objects into springs, water-filled sinkholes (doline lakes), and rivers to propitiate the water divinities. When the smaller offerings were suctioned underground into karstic conduits, they could reappear with resurgent surface waters a considerable distance away from the place of offering.

For example, Pausanias reported that the Lilaeans of Phocis dropped sweetcakes into the karstic Lilaean spring as offerings to the river gods. The ancient Lilaeans claimed that the cakes moved underground and reemerged approximately $18 \mathrm{~km}$ south at the Castalian spring in Delphi (Fig. 1).

Pausanias described the spring of Lilaea as a diurnally rhythmic spring which flowed only at midday, implying that at other times, either its waters did not flow, or they were suctioned downward. Pausanias also indicated that the springflow at midday was accompanied by a bellowing noise, probably caused by air movements in subterranean conduits. Speculatively, the Lilaean spring emerged from an estavelle, which could explain why objects sometimes were pulled down into the structure's throat.

Further, the diurnal rhythmicity could suggest a tidal influence, which is conceivable if a subsurface connection existed between the inland spring and the landsea interface. Lilaea is roughly $22 \mathrm{~km}$ from the Gulf of Corinth, which is a distance comparable to the distances traversed by the "subterranean seas" beneath Cephalonia and beneath inland locations in the Peloponnese, as described by Clendenon (in prep.). A local study of the land-sea interface in Donnalucata, Sicily has shown a semi-diurnal variation in submarine groundwater discharge, and a negative correlation between submarine water fluxes and tidal sea level (Taniguchi et al. 2006; Kontar \& Ozorovich 2006).
The ancient cities of Lilaea and Delphi were situated in adjoining regions dominated by limestones with karstic features, particularly in the mountains (Burdon \& Papakis 1961). Aronis et al. (1961) concluded that although groundwaters on the north flank of Parnassus flow northward to feed the Lilaea spring group, groundwaters from certain overthrust limestones underlain by flysch do not feed these springs, and some waters from the Kalivia block are led southward by a canal, tunnel, and waterfall to irrigate the lands of Delphi. Because these two investigations traced groundwaters only in areas where the resource could feasibly be developed, they did not attempt to examine the possibility of deeper subterranean connections between the Lilaea spring group and the springs of the Delphi region, nor possible connections to the Gulf of Corinth. But given the presence of multiple faults and other hydrogeological complexities in the Parnassus region, an ancient hydrogeologic connection between Lilaea and Delphi could have existed, just as Pausanias described.

\section{SUBTERRANEAN BIFURCATION}

Another account of an incidental karstic water trace associated with ancient religious ritual derives from Arcadia and the adjoining region of Laconia (Fig. 1). Strabo and Pausanias described a karstic Peloponnesian river whose subterranean flow divided while it was still underground, and whose two portions reemerged separately to form the headwaters of two distinct surface rivers in two topographical watersheds. As Fig. 1 shows, the River Alpheus flows generally northwest from the northern Taygetus mountain range, whereas the River Eurotas flows generally southeast.

Pausanias says that at Asea (an ancient town southwest of Tegea), the upper Alpheus and upper Eurotas joined their flows into a single river, which ran as a single watercourse for $4 \mathrm{~km}$, then disappeared underground through a sinkhole. The water then emerged as two rivers with the same names as before. In other words, the downgradient sequence was two surface streams, one combined surface stream that was swallowed underground, and two surface springs that emerged from underground. This phenomenon led to the belief among ancient Greeks that if two wreaths were thrown into the common stream before it disappeared underground, the wreath dedicated to the god of the River Eurotas would reappear in the resurged River Eurotas, and the wreath dedicated to the god of the River Alpheus would reappear in the resurged River Alpheus. 
This ancient account is easily within the realm of karstic possibility. Karstic river confluences and bifurcations exist underground, just as they exist on the openair land surface. Subterranean journeys often disregard surface topography and instead follow hidden pathways to emerge in unpredictable places.

Regarding the wreaths, either both would emerge together in one of the resurged branches, or the wreaths would take independent paths. In the latter case, statistical probability dictates that a given wreath sometimes would emerge in the flow of its like-named resurgence.

Nineteenth-century travelers such as Leake (1830) and Loring (1895) carefully examined the ancient accounts regarding the ill-defined headwaters of the Al- pheus and Eurotas and the repeated descents and resurgences of their main rivercourses. Regrettably, the travelers did not give the same detailed attention to the mouth of the River Alpheus, whose watercourse traverses karstic terranes and whose deltaic waters, in part, were anciently believed to disappear underground and travel through the bed of the Ionian Sea before resurfacing via the subaerial spring of Arethusa in Syracuse, Sicily. Clendenon (in prep.) examines this myth and the similar myth of the River Meander, which likewise traverses karstic regions before emptying into the sea. Albeit implausible in their scales, these myths articulate the physical possibility of focused, long-distance fresh-water flow through karstic submarine conduits in the seabed.

\section{ACKNOWLEDGEMENT}

The author thanks Craig Asquith for his original map and its revision.

\section{REFERENCES}

Aristotle, c. 350 BC: Meteorology.- [Online]. Available from: http://classics.mit.edu/Aristotle/meteorology. html [Accessed 20 $0^{\text {th }}$ March 2009].

Aronis, G., Burdon, D.J. \& K. Zeris, 1961: Development of a karst limestone spring in Greece.- Intern. Assoc. Sci. Hydrol., Groundwater in Arid Zones, 57, 564-585.

Back, W., 1978: Archaeological hydrogeology and hydromythology in the New World.- Unpublished paper presented at the International Symposium on Implications of Hydrogeology to Other Earth Sciences, 11-16 Sept. 1978, University of Montpellier, France.

Back, W., 1981: Hydromythology and ethnohydrology in the New World.- Water Resour. Res., 17, 257-287.

Baird, H.M., 1856: Modern Greece: a narrative of a residence and travels in that country.- Harper \& Bros., New York, 174-175, 214-217.

Baker-Penoyre, J., 1902: Pheneus and the Pheneatike.- J. Hellenic Studies, 22, 228-240.

Boblaye, M., 1835: On terrestrial or epigeic deposits on the surface of the Morea.- In: Jameson, R. (Ed.), The Edinburgh New Philosophical Journal, 18, 1-19.

Brewster, H., 1997: The River Gods of Greece: Myths and mountain waters in the Hellenic world.- I.B. Tauris Publishers, p. 224, London \& New York.
Broad, W.J., 2006: The oracle: the lost secrets and hidden message of ancient Delphi.- Penguin Press, p. 336 New York.

Burdon, D.J. \& N. Papakis, 1961: Methods of investigating the groundwater resources of the ParnassosGhiona limestones.- Intern. Assoc. Sci. Hydro., 57, 143-159.

Clendenon, C.J., 2009a: Hydromythology and the ancient Greek world: an earth science perspective emphasizing karst hydrology.- Fineline Science Press, Lansing, MI, xii-xvi, 305-314, 318-319, 347-363.

Clendenon, C.J., 2009b: Ancient Greek hydromyths about the submarine transport of terrestrial fresh water through seabeds offshore of karstic regions.(in preparation).

Crouch, D.P., 1990: Planning water management for an ancient Greek city.- In: Hydrological Processes and Water Management in Urban Areas (Proceedings of the Duisberg Symposium, April 1988), IAHS Publ., 198, 271-276.

Crouch, D.P., 1993: Water management in ancient Greek cities.- Oxford University Press, Oxford and New York, 77-78, 94-96, 133-135.

Crouch, D.P., 1996: Environmental geology of ancient Greek cities.- Environ. Geol., 27, 233-245. 
Crouch, D.P., 2003: Geology and settlement: Greco-Roman patterns.- Oxford University Press, p. 384, New York.

Dodwell, E., 1819: A classical and topographical tour through Greece, during the years 1801, 1805, and 1806 (2 vols.).- Rodwell \& Martin, London, Vol. 2, 223-228.

Fetter, C.W., Jr., 2004: Hydrogeology: a short history, part 1.- Ground Water, 42, 790-792.

Fleury, P., Bakalowicz, M. \& G. de Marsily, 2007: Submarine springs and coastal karst aquifers: a review.- J. Hydrol., 339, 79-92.

Frazer, J.G., 1898: Pausanias's description of Greece, translated with a commentary (6 vols.).- Macmillan, London, Vol. 4, 230-235, 262-265, 268-275.

Gell, W., 1810: The itinerary of Greece, with a commentary on Pausanias and Strabo: Argolis.- Thomas Payne, London, 79-80, 82-84, 158-159.

Gell, W., 1823: Narrative of a journey in the Morea.Longman, Hurst, Rees, Orme \& Brown, London, 382-383.

Hale, J.R., Zeilinga de Boer, J., Chanton, J.P. \& H.A. Spiller, 2003: Questioning the Delphic oracle.- Sci. Am., 289, 66-73.

Herodotus, c. 440 BC: Histories.- Transl. G. Rawlinson, 1860, Everyman's Library, Book 6, Chapter 76, J.M. Dent \& Sons, London.

Higgins, M.D. \& R.A. Higgins, 1996: A geological companion to Greece and the Aegean.- Cornell University Press, Ithaca, NY, 45-49, 70-85.

Kontar, E.A. \& Y.R. Ozorovich, 2006: Geo-electromagnetic survey of the fresh/salt water interface in the coastal southeastern Sicily.- Continent. Shelf Res., 26, 843-851.

Kraft, J.C., Rapp, G.R., Kayan, I. \& J.V. Luce, 2003: Harbor areas at ancient Troy: sedimentology and geomorphology complement Homer's Iliad.- Geology, 31, 163-166.

Kraft, J.C., Rapp, G.R., Gifford, J.A. \& S.E. Aschenbrenner, 2005: Coastal change and archaeological settings in Elis.- Hesperia, 74, 1-39.

Kranjc, A., 2000: Karst water research in Slovenia.- Acta Carsologica, 29, 117-125.

LaMoreaux, P.E., 1991: History of karst hydrogeological studies.- In: Proceedings of the International Conference on Environmental Changes in Karst Areas, IGU-UIS, 15-27 Sept. 1991, Universita di Padova, Italy. Quaderni del Dipartimento di Geografia, 13, 215-229.

LaMoreaux, P.E. \& J.W. LaMoreaux, 2007: Karst: the foundation for concepts in hydrogeology.- Environ. Geol., 51, 685-688.
Leake, W.M., 1830: Travels in the Morea (3 vols.).- John Murray, London, Vol. 1: 122-125; Vol. 2: 266-267, 340-343, 469-481; Vol. 3: 36-93, 113-114, 135-156, 339-351.

Lemon, M. (Ed.), 1999: Exploring environmental change using the integrative method.- CRC Press, Boca Raton, FL, 126-129.

Loring, W., 1895: Some ancient routes in the Peloponnese.- J. Hellenic Studies, 15, 25-89.

Mariolakos, I.D., 2005: Karstic structures and geodynamic regime in the Greek mythology on the footsteps of Poseidon and Hercules from Viotia up to the Cape Tainaro, Lakonia. Post-congress tour led by Ilias D. Mariolakos, 27-28 Aug. 2005, Fourteenth International Congress of Speleology, Athens, Greece.

Mariolakos, I. D. \& D. I. Mariolakos, 2004: The Argon Field in Arcadia, the sinkhole of Nestani village, god Poseidon and the submarine Dini Springs in the Argolic Gulf (Peloponnisos, Greece): a geomythological approach of the Poseidon's birth.- In: Proceedings of the Tenth International Congress of the Geological Society of Greece, 15-17 Apr. 2004, Thessaloniki. Bull. Geol. Soc. Greece, 36, 11461153.

Milanovic, P.T., 2004: Water resources engineering in karst.- CRC Press, Boca Raton, FL, 23, 50.

Morfis, A. \& H. Zojer (Eds.), 1986: Karst hydrogeology of the central and eastern Peloponnesus.- Fifth International Symposium on Underground Water Tracing, Athens, Greece, 1986. Contributions to Hydrogeology (Beitrage zur Hydrogeologie), Vol. 37-38, 1-301.

Ovid, c. 10 AD: Metamorphoses.- Transl. A.D. Melville, 1986, Book 15, Oxford University Press, New York.

Pausanias, c. 175 AD: Description of Greece.- Transl. W.H.S. Jones, 1933, Loeb Classical Library, Vol. 3, Books 6-8.21, Harvard University Press, Cambridge, MA.

Piccardi, L. \& W.B. Masse (Eds.), 2007: Myth and geology.- The Geological Society of London, Special Publication, 273, 227-244, 329-340.

Strabo, c. 15 AD: Geography.- Jones, H.L., transl., 19241928, Loeb Classical Library, Vol. 3, Books 6-7 (1924); Vol. 4, Books 8-9 (1927); Vol. 5, Books 1012 (1928), Harvard University Press, Cambridge, MA.

Taniguchi, M., Burnett, W.C., Dulaiova, H., Kontar, E.A., Povince, P.P. \& W.S. Moore, 2006: Submarine groundwater discharge measured by seepage meters in Sicilian coastal waters.- Continent. Shelf Res., 26, 835-842. 
Vitaliano, D.B., 1968: Geomythology: the impact of geologic events on history and legend, with special reference to Atlantis.- J. Folklore Inst., 5, 5-30.

Vitaliano, D.B., 1971: Atlantis: a review essay.- J. Folklore Inst., 8, 66-76.

Vitaliano, D.B., 1973: Legends of the earth: their geologic origins.- Indiana University Press, Bloomington, 65-66.

White, W.B., 2007: A brief history of karst hydrogeology: contributions of the NSS.- J. Cave Karst Studies, 69, 13-26.
Williams, P., 2008: World heritage caves and karst: a thematic study.- [Online]. Available from: http:// cmsdata.iucn.org/downloads/cavesandkarstwh.pdf [Accessed 20 ${ }^{\text {th }}$ March 2009].

Zangger, E., 1991: Prehistoric coastal environments in Greece: the vanished landscapes of Dimini Bay and Lake Lerna.- J. Field Archaeol., 18, 1-15. 